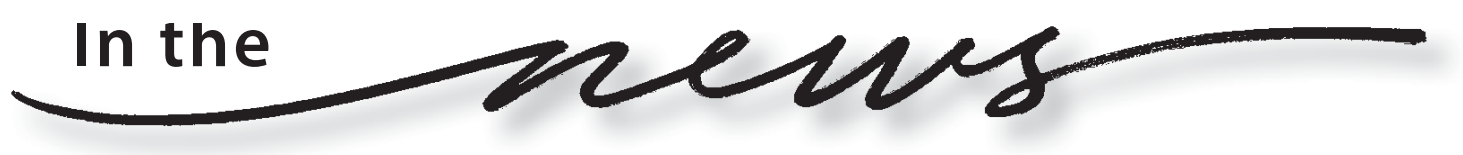

In support of ACRL President Camila Alire's strategic focus of advocating for academic libraries, this issue includes an article in the Charting Our Future series that focuses on an overlooked aspect of advocacy: training. In "Training programs in academic libraries," authors Frances C. Wilkinson and Linda K. Lewis bring home the point that libraries should be as committed to educating their staff as they are to educating their users and provide examples of positive internal and off-site training options.

ACRL's Council of Liaisons (COL) carries out a program of in-depth liaison activities with targeted professional associations. COL brings to the attention of nonlibrary associations how library resources and services can contribute to their mission and goals and brings information and higher education issues of other associations to the attention of the ACRL Board and membership. In "Stranger in a promising land" (p. 360), Larry Hardesty reports back on his experience attending the 25th Annual Conference on the First-Year Experience (FYE). Although one of the few librarians in attendance, he was well-received and discovered that librarians and the library are viewed as valuable partners by many other campus areas, especially when dealing with FYE.

COL is accepting applications for liaisons-see the information box accompanying this article or visit the Web site at www. ala.org/ala/acrl/acrlissues/councilofliaisons /liaisons.htm.

The results are in! Congratulations to Julie Todaro, ACRL's newly elected vice president/ president elect. Information about Todaro and incoming President Pamela Snelson, along with complete election results, can be found on page 375 .

-Stephanie Orphan, Editor-in-chief sorphan@ala.org

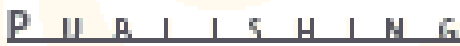

\title{
AICIS 2006
}

\section{Community, Collaboration, and Collections: The Writings of Ross Atkinson}

edited by Robert Alan and Bonnie MacEwan, with an introduction by Sarah Thomas

ISBN 0-8389-8361-8*8.25' $x 11^{\circ}$ * softcover * 320 pages *

Price: $\$ 75$ - ALA Member Price $\$ 67$

For more than twenty years, Ross Atkinson provided the library community with insightful, articulate writing about libraries and the changing character of library collections. This work consists of a selection of Atkinson's most significant publications and is eloquently introduced by Sarah Thomas. 